Article

\title{
EFFECT OF STIMULATION TO GROW BABY IN BUKITTINGGI CITY IN 2018
}

\author{
Wiwit Fetrisia ${ }^{1}$, Aisyah Elyanti ${ }^{2}$, Yantri Maputra ${ }^{3}$ \\ ${ }^{1}$ Master of Master Degree Program in Midwifery Faculty of Medicine University of Andalas \\ ${ }^{2}$ Faculty of Medicine Medical Education Andalas University \\ ${ }^{3}$ Psycology Faculty of Medicine Andalas University
}

\begin{tabular}{l} 
SUBMISSION TRACK \\
\hline Recieved: March 28, 2017 \\
Final Revision: May 03, 2017 \\
Available Online: May 15, 2017 \\
KEYWORDS \\
\hline Stimulation, Baby 0-6 months, Denver II Test \\
CORRESPONDENCE
\end{tabular}

Phone: 085375727272

E-mail: wiwitfetrisia62@gmail.com

\begin{abstract}
A B S T R A K
The initial stage of a human's life in infancy is considered important because at this time the foundations of personality are laid down which will give color when they grow up. The role of parents is very necessary in providing early stimulation. Stimulation is stimulation that comes from the baby's outer environment. The baby health service coverage in 2014 in Bukittinggi was 88.4\%, lower than Padang city as much as $90.6 \%$. It is known that the number of infants aged 0-1 years in Padang city amounted to 3,498 people, while in Bukittinggi city only 629 people. Supposedly with a small number of infants achieving early detection of infant growth and development is better than the number of babies in a larger city. The design of this study was a quasi-experimental design with two group pretest-posttest with the control group to identify the effect of stimulation on infant growth and development before and after the intervention, which was carried out from November 2017 - August 2018, in the environmental health center of Bukittinggi City Health Office. The population is infants with ages 0 - 6 months, and the number of samples taken is 46 people. The results of the study carried out with the Wolcoxon test, obtained there were differences in development before and after the intervention was given to the intervention group $p=0,000$, there was a development difference in the control group $p=0.014$, there were differences in growth before and after the intervention $p=$ 0.000 , there was no difference growth in the control group $p=0.083$. It can be concluded that stimulation plays a role in preventing delays in growth and development in infants 0-6 months. From this study health workers can socialize about how to stimulate babies to mothers for early prevention of growth and development disorders in infants.
\end{abstract}




\section{INTRODUCTION}

The process of growth and development begins in infancy and toddlers, and this is a very important process, because at this time the process of growth and development determines the future of the baby both physically, mentally and behavior. The rate of growth and development at each age stage is not always the same, depending on heredity, nutritional consumption, the treatment of parents and adults, and the environment (Soetjiningsih, 2014).

The initial stage of a person's life, under three years of age (toddler) is considered important because in this period, the basics of personality that will give color when the baby grows up. Premature stimulation itself is a stimulus that is carried out since the newborn baby (even better since the fetus 6 months in the womb) is carried out every day, to stimulate all sensory systems from hearing, sight, touch, confusion, taste. Stimulation must be done in a pleasant atmosphere and excitement between mother and baby / toddler (Soetjiningsih, 2014).

Stimulation is stimulation (vision, speech, hearing and touching) that comes from the outside environment of the baby. Stimulation is an important thing in baby growth and development. Babies who get stimulated directed and regular will develop faster than babies who are lacking or not getting stimulation (Alimul, 2009). Hurlock (2009) suggests that a stimulating environment is one of the factors driving baby's development. A stimulating environment encourages good physical and mental development, while a non-stimulating environment causes the development of a baby under his ability. Giving stimulation to the baby will be more effective when paying attention to the needs of the baby in accordance with the stage of development(Hurlock, 2009).

Early in cognitive development, each baby is different in the motor sensory stage. At this stage the cognitive state of the baby will show motor activities, which are the result of sensory stimulation. Stimulation activities include a variety of activities to stimulate baby development such as exercise, talking, thinking, independent and socializing. This stimulation activity can be done by parents or family whenever there is a chance or everyday. For normal baby development, growth and maturity of body functions are needed at the same time. Infant growth and development must be followed by several stages of development (Alimul, 2009).

The readiness of mothers to care for babies to achieve optimal growth and development becomes very important, especially in the care of babies in their early life. This is where the role of parents, especially mothers, is indispensable in fostering and monitoring infant growth and development, especially as a provider of early stimulation. If at that time the baby does not get proper treatment and guidance, the baby can experience emotional, social, mental, intellectual and moral developmental disorders which will determine the attitude and values of a person's behavior in the future. The cause of delays in a baby's growth and development is influenced by several causes such as genetic (down syndrome, turner syndrome, etc.), and environmental 
factors such as nutrition, biological, physical, psychosocial and family (Nurjaya, 2006).

Psychosocial factors in it are less stimulating factors carried out by mothers / caregivers who directly care for babies. This factor can be caused by the mother of the worker, lack of knowledge about how to stimulate the baby, and the age factor of the immature mother (Alimul, 2009).

Research conducted by Nurjaya (2006) on the role of early stimulation of cognitive development of infants. In this study showed that stimulation can play a role for cognitive development, and parents play a role in the success of baby stimulation.

Bukittinggi City is the second largest city after the city of Padang in the province of West Sumatra. Based on data from the City / District Health Office of West Sumatra Province, the coverage of infant health services in 2014 was $88.4 \%$, lower than the city of Padang as much as $90.6 \%$. It is known that the data obtained from the West Sumatra Province Statistic Center (BPS) 2015, the number of infants in the age range 0-1 years in the city of Padang amounted to 3,498 people, while in the city of Bukittinggi only 629 people. With a small number of babies, the achievement of early detection of infant growth is better than cities with larger numbers of babies. Therefore, researchers are interested in conducting research in the area of Bukittinggi, by looking at the effect of stimulation on infant growth and development (Dinkes, 2014).

\section{METHOD}

This research is a quantitative research with a quasi-experiment research design. Quasi-experiment is a research that has impact treatment and measurement. The design of this study was two group pretest-posttest with the control group to identify the effect of stimulation on infant growth and development before and after stimulation (Hastono, 2011 ; Dahlan, 2013).

This research has been carried out in all health centers in the city of Bukittinggi. The time of the study was carried out from the title received until the final exam, starting from July 2017 to August 2018. The population in this study were infants aged 0-6 months. This study uses non-probability sampling techniques with sampling consecutive sampling. consecutive sampling is that all subjects who come and meet the selection criteria are included in the study until the required number of subjects is fulfilled and within a certain period of time (Dahlan, 2010; Notoadmojo, 2012). The number of samples used for this study were 46 babies. Data collection was carried out by giving questionnaires for maternal characteristic data to be filled in, then researchers examined the development and growth of infants by performing Denver II tests and weighing and measuring weight, body length and infant head circumference (pretest). After the development and developmental delay of the tests and measurements have been found, the baby is the inclusion criteria of the study. Then the researchers taught how to stimulate the baby in the mother to train infant development in accordance with the age group.

\section{RESULTS}

Table 1 shows that after stimulation in the intervention group, infant development became normal in 21 $(91.3 \%)$ respondents, and two (8.7\%) 
respondents did not experience improvement. In the control group, the baby's development became normal in six (26.1\%) respondents, and the permanent ones were found in 17 (73.9\%) respondents. In the intervention group from the results of statistical tests obtained $\mathrm{p}$ value $0.000(\mathrm{p}<0.05)$ means that there is a development effect before and after being given intervention in the development of 0-6 months infants. In the control group from the results of statistical tests obtained $\mathrm{p}$ value 0.014 (p $<0.05$ ) means that there is a significant development effect on the development of infants 0-6 months even though no intervention is given.

Table 1 Development Before and After Giving Intervention

\begin{tabular}{cccccc}
\hline \multirow{2}{*}{$\begin{array}{c}\text { Results } \\
\text { Screening }\end{array}$} & \multicolumn{4}{c}{ Control group } \\
\cline { 2 - 5 } & Pre-Test & \multicolumn{2}{c}{ Post-Test } & $\boldsymbol{p}$ \\
\cline { 2 - 5 } & $\mathbf{f}$ & $\mathbf{\%}$ & $\mathbf{f}$ & $\mathbf{\%}$ & value \\
\hline Normal & 0 & 0 & 6 & 26,1 & 0,014 \\
Suspect & 23 & 100 & 17 & 73,9 & \\
\hline Total & $\mathbf{2 3}$ & $\mathbf{1 0 0}$ & $\mathbf{2 3}$ & $\mathbf{1 0 0}$ & \\
\hline
\end{tabular}

\begin{tabular}{cccccc}
\hline \multirow{2}{*}{ Results } & \multicolumn{5}{c}{ Intervention group } \\
\cline { 2 - 5 } Screening & Pre-Test & \multicolumn{2}{c}{ Post-Test } & $\boldsymbol{p}$ \\
\cline { 2 - 5 } & $\mathbf{f}$ & $\mathbf{\%}$ & $\mathbf{f}$ & $\mathbf{\%}$ & value \\
\hline Normal & 0 & 0 & 21 & 91,3 & 0,000 \\
Suspect & 23 & 100 & 2 & 8,7 & \\
\hline Total & $\mathbf{2 3}$ & $\mathbf{1 0 0}$ & $\mathbf{2 3}$ & $\mathbf{1 0 0}$ & \\
\hline
\end{tabular}

Table 2 shows that before being given stimulation in the intervention group the growth of infants who were not in accordance with age were in 19 (82.6\%) respondents, and in the control group were $22(95.7 \%)$ respondents. After stimulation in the intervention group, the baby's growth was in accordance with the age of $14(60.9 \%)$ respondents, and in the control group the baby's growth was in accordance with the age of $8(34.8 \%)$ respondents. In the intervention group from the results of statistical tests obtained $p$ value $0,000(p<0.05)$, meaning that there are differences in growth before and after being given intervention in the growth of infants 0-6 months. In the control group from the results of statistical tests obtained $\mathrm{p}$ value 0.083 ( $\mathrm{p}$ > $0.05)$, meaning that there is no difference in growth in the growth of infants 0-6 months.

Table 2 Growth Before and After Giving Intervention

\begin{tabular}{|c|c|c|c|c|c|}
\hline \multirow{3}{*}{$\begin{array}{c}\text { Results } \\
\text { Screening }\end{array}$} & \multicolumn{5}{|c|}{ Control group } \\
\hline & \multicolumn{2}{|c|}{ Pre-Test } & \multicolumn{2}{|c|}{$\begin{array}{c}\text { Post- } \\
\text { Test }\end{array}$} & \multirow{2}{*}{$\begin{array}{c}p \\
\text { valu } \\
e\end{array}$} \\
\hline & $\mathbf{f}$ & $\%$ & $\mathbf{f}$ & $\%$ & \\
\hline $\begin{array}{l}\text { Sesuai } \\
\text { Umur }\end{array}$ & 1 & 4,4 & 8 & $\begin{array}{c}34 \\
8\end{array}$ & \\
\hline $\begin{array}{l}\text { Tidak } \\
\text { Sesuai } \\
\text { Umur }\end{array}$ & 22 & 95,7 & 15 & $\begin{array}{c}65, \\
2\end{array}$ & $\begin{array}{c}0,00 \\
3\end{array}$ \\
\hline Total & 23 & 100 & 23 & 100 & \\
\hline \multirow{3}{*}{$\begin{array}{c}\text { Results } \\
\text { Screening }\end{array}$} & \multicolumn{5}{|c|}{ Intervention group } \\
\hline & \multicolumn{2}{|c|}{ Pre-Test } & \multicolumn{2}{|c|}{ Post-Test } & $p$ \\
\hline & $\mathbf{f}$ & $\%$ & $\mathbf{f}$ & $\%$ & $e$ \\
\hline $\begin{array}{l}\text { Sesuai } \\
\text { Umur }\end{array}$ & 4 & 17,4 & 14 & 60,9 & \\
\hline $\begin{array}{l}\text { Tidak } \\
\text { Sesuai } \\
\text { Umur }\end{array}$ & 19 & 82,6 & 9 & 39,1 & $\begin{array}{c}0,00 \\
0\end{array}$ \\
\hline Total & 23 & 100 & 23 & 100 & \\
\hline
\end{tabular}

\section{DISCUSSION}




\section{a. Effect of Stimulation on Baby's Growth and Growth Before Being Stimulated (Pre-Test)}

In the growth of the baby it was found that before being given stimulation in the intervention group the growth of infants who were not in accordance with age were in 19 $(82.6 \%)$ respondents, and in the control group were $22(95.7 \%)$ respondents.

Infancy starts from the age of $0-12$ months which is characterized by rapid growth and physical changes accompanied by changes in nutrient requirements. During this period, the baby is completely dependent on care and feeding by his mother. Babies are creatures that are present in the world with an innate mechanism to please others, and only ask for a reply in the form of the right environmental conditions, which allows the growth of "seeds of compassion" that naturally exist in him (Laurent, 2009). Therefore giving stimulation or stimulation to the baby is strongly influenced by the role of the mother or caregiver who directly interacts with the baby. From the provision of stimulation given the mother must know how to provide the right stimulation so that the stimulation given is optimal.

Based on research that has been carried out development and growth that experience delays influenced by education and maternal age. From the data obtained the average mother's education was in high school education as much as $69.6 \%$, the mother did not know how to stimulate infant stimulation, besides that there were two respondents who remained in late growth and development, based on the research the mother had under 30 years of age and mother work outside the house. This shows that based on the results of good growth and development research carried out by mothers who have an average age of 30 years and even though the interaction is carried out more than 8 hours, but the interaction carried out together with the activities of mothers in working as office workers in kindergarten education, so that the stimulation given to the baby is not intensive and maximal. From the interviews conducted by the mother said that although the mother and baby are always together, the interaction is not optimal. Babies who lack stimulation can experience growth deviations or even persistent disturbances. This can also be affected because the mother is less willing or lazy to teach the baby and communicate with the baby as needed. This is supported by the study of Widaningsih (2012) on the results of the study some respondents still experience a decrease in function, which can be caused by parents who are not really in stimulating at home. Education is indirectly related to mother's knowledge, good knowledge will influence the way mothers stimulate. Therefore socialization about how to stimulate babies is important to be informed by health workers to mothers who have babies. But there are also three mothers who work outside the home with babies who have been given intervention with normal growth and development. From the data obtained, the mother works as a trader, so that the mother's work does not prevent the mother from interacting with her baby, so that stimulation can 
be given to the baby. Therefore, the field of work can also influence the provision of stimulation to the baby. The work of a mother who has a leader in the place of work affects the mother in giving stimulation because of the work demands of the leader, but if the work of the mother is a trader, then the mother is the one who arranges his own work, so there is no demand that prevents the mother from caring for her baby even though the mother is work, so that stimulation can still be given.

\section{b. The Effect of Stimulation on} Baby's Growth and Development After Being Stimulated (Post-Test

\section{1) Development and growth in the intervention group}

From the results of statistical tests in the intervention group it was concluded that there is a stimulation effect on the development and growth of the baby, it can be seen from the significant differences before and after the intervention, with a significant level of 0.000 (p $<0.05)$ in infant development and $0,000(\mathrm{p}<0,05)$ for baby growth. This states that the stimulation given is meaningful because it can have an effect on the development of infants 0-6 months.

The development of the intervention group and the control group at the posttest was obtained from the results of statistical tests $p$ value of $0.003(p<0.05)$ meaning that there were significant development differences after being given intervention in the intervention group and the control group on the development of infants 0-6 months.

An important period in the process of baby growth and development is the first five years of individual life (the golden period) (Alimul, 2009). Stimulation has an important role to increase the growth and development of infants, especially cognitive, affective and psychomotor functions (Alimul, 2009). This is strengthened by the results of research from Fitriani (2017) and guidelines for the management of early stimulation, detection and intervention of child development Depkes RI (2016) which is stimulating the basic abilities of infants aged 0-6 years with stimulation can stimulate the baby's ability to grow and develop optimal.

Environmental factors can affect the baby's growth and development after birth (postnatal factor). Newborns must successfully pass the transition period, from an organized system that is largely dependent on maternal organs, to a system that depends on the genetic abilities and homeostatic mechanisms of the baby itself, with stimulation provided by the mother to the baby will improve development and infant growth in terms of gross motor, fine motoric, psychosocial and language (Desininggrum, 2012).

Based on the research that has been done a good baby growth and development is also supported by mothers who have a lot of time in giving attention and giving optimal stimulation to the baby so that the 
baby's growth and development will be normal and appropriate, because based on research all mothers have interaction $>8$ hours per day and most of them are housewives so that the mother's interaction in stimulating her baby is more optimal. Apart from the long interaction, the mother can stimulate the baby's development intensively and can be done by playing method, so that it can be seen especially from the baby's development there is an increase in development through the denver II test.

\section{2) Development and growth in the control group}

From the results of statistical tests obtained in the control group obtained conclusions there is no effect of stimulation on the development and growth of infants, can be seen from the $p$ value of $0.014 \quad(\mathrm{p}<0.05)$ in infant development and $0.083(p>0.05)$ in infant growth, means that in the control group there was no effect of stimulation on the growth of infants 0-6 months.

Babies who experience growth retardation if they are not immediately overcome, delays in growth and development will continue. The impact of babies with gross motor disorder will experience a balance disorder, in this case it would be better for parents to pay attention to the gross motoric of the baby, because if it can be known early, then the stimulation given will be faster to give. Likewise for the physical growth of the baby, the physical growth of the baby is well supported by good nutrition, with the development of the baby's brain will take place optimally. Baby's physical skills will develop as a result of the development of parts of the brain that regulate the baby's sensory and motor system (Suyanto, 2014).

From the research that has been done, education is an important part of a mother's knowledge in stimulating her baby. Mother does not have knowledge about how to stimulate her baby. It is important for parents to understand the baby's developmental delays, while also understanding how to respond appropriately. That way, babies can be handled properly if they experience delays. There are several factors that influence the growth and development of the baby not developing according to the age of the baby, including maternal education factors, where from the results of the study most of the mother's education was in high school education as much as $69.6 \%$.

The growth of the intervention group and the control group at the posttest was obtained from the results of statistical tests $p$ value of 0.413 ( $p>0.05$ ) meaning that there were no significant differences in growth after being given intervention in the intervention group and the control group on the development of infants 0-6 months.

But in the control group there were also some babies who experienced changes in development and growth without being given intervention. It can be 
seen from the results of the study that there were six respondents without being given normal development interventions.

From the research that has been carried out it can be seen from six respondents, the mother of the baby is at a very mature age, that is, with an average age above 30 years, from a mature age the mother has experienced how to stimulate infant development, and the mother knows about the need to fulfill baby's nutritional needs so that growth grows optimally. In addition, this occurs due to the development in infancy as well as the process of increasing and maturity of personal abilities and social abilities in accordance with the increasing age of the baby. This is in line with the theory delivered by Alimul (2009), that for normal infant development growth and maturity of body functions is needed at the same time. The development and growth of the baby must be followed by several stages of development. The other factors that affect growth and development in this baby is that the nutrition given by his parents is quite good, that is in accordance with the nutritional needs of the baby so that the baby's development becomes normal and the development of the baby's motor in accordance with his age

\section{CONCLUSION}

The results of this study indicate that stimulation affects the baby's growth and development in Bukittinggi in 2018. Therefore, it is important to be informed and applied that stimulation can help the growth and development of infants who experience growth and development disorders, and is important to socialize and provide training in how to stimulate the baby to mothers who have babies so that early detection of delays in infant growth and development can be immediately known, so that it can be prevented by growth and developmental disorders in infants. 


\section{REFERENCES}

1. Alimul A. Ilmu Kesehatan Pada Anak Untuk Mahasiswa kebidanan. Jakarta : Salemba Medika; 2009. hal 32-22.

2. Dahlan S. Besar Sampel \& Cara Pengambilan Sampel dalam Penelitian Kedokteran \& Kesehatan. Jakarta : Salemba Medika; 2010. hal 135-136.

3. Dahlan S. Statistik Untuk Kedokteran dan Kesehatan. Jakarta : Salemba Medika; 2013. hal 85-87.

4. Departemen Kesehatan RI. Pedoman Penatalaksanaan Stimulasi, Deteksi, dan Intervensi Dini Tumbuh Kembang Anak di Tingkat Pelayanan Kesehatan Dasar. Jakarta; 2016. hal 3-9.

5. Desininggrum. Buku Ajar Psikologi Perkembangan Anak. Semarang : UPT UNDIP Semarang; 2017. hal 62-87.

6. Fitriani O. Stimulasi, Deteksi dan Intervensi Dini Orang Tua terhadap Pencegahan Penyimpangan Pertumbuhan dan Perkembangan Anak Balita The Indonesian Journal Of Health Scienc. Vol 1, 2017.

7. Hastono SP, Sabri L. Statistik Kesehatan. Jakarta : PT. Raja Grafindo Persada; 2011. hal 114.

8. Hurlock EB. Psikologi Perkembangan Anak. Edisi 6. Jakarta : Erlangga; 2011. Hal 15-18.

9. Hertzman $\mathrm{C}$, Boyce $\mathrm{T}$. How experience gets under the skin to create gradients in developmental health. Annu Rev Public Health 2010; 31: 329-47

10. Muslihatun WN. Asuhan Neonatus Bayi dan Balita. Yogyakarta : Fitramaya; 2010. hal 4755.

11. Notoadmodjo S. Metodelogi Penelitian Kesehatan. Jakarta : Rineka Cipta; 2012. hal 84-98.

12. Nurjaya. Peranan Stimulasi Dini Terhadap Perkembangan Kognitif Bayi. 2006 (Diunduh tanggal 4 Oktober 2017). 〈https://rsudbima.wordpress.com/2009/03/09/101/>

13. Soetjiningsih. Tumbuh Kembang Anak. Jakarta : EGC; 2014. hal 1-30.

14. Suyanto. Dukungan Keluarga Dan Sosial Dalam Pertumbuhan Dan Perkembangan Personal Sosial, Bahasa Dan Motorik Pada Balita Di Kabupaten Banyuma. Jurnal Kesehatan Masyarakat. 2014 (Diunduh tanggal $24 \quad$ November 2017 dari http://journal.unnes.ac.id/nju/index.php/kemas)

15. Thompson, R. A., \& Nelson, C. A. Developmental science and the media: Early brain development. American Psychologist; 2012.

16. Umemura T, Jacobvitz D, Messina S \& Hazen N. Do Toddler Prefer The Primary Caregiver Or The Parent With Whom They Feel More Secure ? The Role Of Toddler Emotion. Infant \& Behavior Development 36.102-114. 2013 (Diunduh tanggal 24 November 2017 dari http://www.sciencedrect.com/science/article/pii/S0163638312001117)

17. Van Rie A, Harrington PR, Dow A, Robertson K. Neurologic and neurodevelopmental manifestations of pediatric HIV/AIDS: a global perspective. Eur J Paediatr Neurol. 2007; 11: 1-9.

18. Walker SP, Wachs TD, Gardner JM, et al. Child development: risk factors for adverse outcomes in developing countries. Lancet. 2007; 369: 145-57.

19. Widaningsih. Pengaruh Stimulasi Deteksi Dini Tumbuh Kembang (DDTK) Terhadap Perkembangan Anak Usia 4-24 Bulan Di Wilayah Kerja Puskesmas Cinunuk Kabupaten Bandung.Bhakti Kencana Medika. Volume 2, No. 4, 2012. 


\section{BIOGRAFI}

First Author Wiwit Fetrisia Earned Her Diploma III Of Midwifery Degree From Stikes Prima Nusantara Bukittinggi In 2009, And Then Her Bachelor's Degree Of Educator Midwife, Northern Sumatera University In 2011 And Later Her Master's Degree Midwifery Departement, Faculty Of Medicine At Andalas University. Ever Received A Research Grant In 2014 From Kemenristekdikti. Currently Interested In Researdch For The Development Of Health, Especially Midwifery.

Second Author Dr. dr. Aisyah Ellyanti Sp.KN, M. Kes Graduated From Andalas University, Padjajaran University, Padjajaran University. She Is Lecturer Of Andalas University. Nuclear Medicine Specialist Education From Padjajaran University In 2005. Lecturer Of Medical Education Departement Of FK UNAND Since 2005, Coordinator Education Section Physics Since 2005-2010 Faculty Of Medicine Andalas University, Assistant Dean I Since 2006-2010 Faculty Of Medicine Andalas University, Head Of Installation Nuclear Medicine Sice 20052009, at the M. Djamil Hospital in Padang.

Third Author Yantri Maputra, MED, Ph.D, M. Kes Graduated Doctoral Program From Kebangsaan Malaysia University, And Chair Of The Psychology Education Departement At Andalas University 